\title{
Nationality and Equal Political Rights: A Necessary Link?
}

\begin{abstract}
Andreas Samartzis*
Main justifications for regarding common nationality as a necessary condition for holding equal political rights - Critique of collective self-determination, equal stakes, nature of political activity, and stability justifications - Rejection of the incommensurability of legitimacy and justice - Socioeconomic interdependence and liberal democratic values as the normative grounds for equal stakes - Risk of entrenchment of hostility among national groups as a consequence of a competitive conception of political activity - Instrumental value of stability - Stability through democratic inclusion - Possibility of sustainable pluralism through deliberative democracy - Modified version of the equal stakes argument Equal political rights on the basis of long-term residence - Association of citizenship with nationality in contemporary European states - Redefinition of citizenship as top-down redefinition of nationality - Need to reconceptualise equal political rights independently of citizenship - Legal argument for interpreting references to popular sovereignty in national constitutions in accordance with long-term residence, rather than nationality - Available legal remedies
\end{abstract}

\section{INTRODUCTION}

The link between citizenship and equal political rights has been synonymous with democracy ever since its first instantiation in classical Athens. Although the differentiation between citizens and non-citizens was significant even in nondemocratic city-states, it was in democracies that citizenship came to be linked to an equal right of participation in collective decision-making through voting on concrete issues, voting for office, and being eligible to hold office through

${ }^{*} \mathrm{PhD}$ candidate at Magdalene College, University of Cambridge. I am grateful to Dr Lars Vinx for his generous feedback. Any mistakes remain my own.

European Constitutional Law Review, 17: 636-663, 2021

(C) The Author(s), 2022. Published by Cambridge University Press on behalf of European Constitutional Law Review. This is an Open Access article, distributed under the terms of the Creative Commons Attribution licence (https://creativecommons.org/licenses/by/4.0/), which permits unrestricted re-use, distribution, and reproduction in any medium, provided the original work is properly cited. doi: $10.1017 / S 1574019621000420$ 
election or lottery. ${ }^{1}$ It is, therefore, scarcely surprising that, as the kingdoms of Europe transformed, between the eighteenth and twentieth centuries, into secular nation-states and, finally, into the mass democracies with which we are familiar, the modern state adapted this link by granting equal political rights to its nationals. Whether the dominant national narrative is based on ethnic or civic nationalism, ${ }^{2}$ citizenship and nationality are for the most part treated as one, sometimes to the denial of existing substate nationalities. ${ }^{3}$ The citizenship laws of virtually every European state today distribute equal political rights on the basis of who belongs to the nation. They treat citizenship and nationality as equivalents and thus set national belonging as a condition for holding equal political rights. In doing so, they typify and perpetuate a system of national democracies. In some European states, this mode of distribution is constitutionally entrenched. The federal constitutional court of Germany and the constitutional court of Austria have both interpreted their states' constitutions in a way that makes all consequential political rights inseparable from citizenship. ${ }^{4}$ In the view of the Greek council of state, the Greek constitution demands that naturalisation must be based on substantive criteria sufficient to verify the applicant's integration in Greek society. ${ }^{5}$

Integration into the national culture as a condition for citizenship acquisition as well as for acquiring the status of long-term resident in fact figures ever more prominently in the law of European states through the introduction of citizenship tests and integration contracts, which often aim to verify that the non-citizen has become familiar with the national culture. ${ }^{6}$ The requirement of integration is also prominent in EU law, which both recognises the member states' authority to require the compliance of non-citizens with integration measures, ${ }^{7}$ and accepts cultural integration as a relevant factor in expulsion proceedings. ${ }^{8}$ Through these

${ }^{1}$ J. Ober, Democracy and Knowledge: Innovation and Learning in Classical Athens (Princeton University Press 2008).

${ }^{2}$ R. Brubacker, Citizenship and Nationhood in France and Germany (Harvard University Press 1992).

${ }^{3}$ See French Constitutional Council, decision 91-290 DC of 9 May 1991 on the unconstitutionality of a statute referring to the Corsican people as a nation; see also ECtHR 27 March 2008, No. 26698/05, Tourkiki Enosi Xanthis and Others v Greece on Art. 11 ECHR, condemning the Greek state for denying an association the possibility to include the adjective 'Turkish' in its name on public order grounds.

${ }^{4}$ BVerfGE 83, 37; BVerfGE 83, 60; VfGH 30.06.2004, G 218/03, p. 47-48.

${ }^{5}$ Greek Council of State 460/2013, para. 10.

${ }^{6}$ For an overview, see L. Orgad, The Cultural Defense of Nations: A Liberal Theory of Majority Rights (Oxford University Press 2015) ch 3. I am grateful to an anonymous reviewer for suggesting that I address this point.

${ }^{7}$ Art. 7(2) of Directive 2003/86/EC; Arts. 5(2) and 15(3) of Directive 2003/109/EC.

${ }^{8}$ Art. 28 of Directive 2004/38/EC. 
provisions, a concern for the implications of increasing cultural heterogeneity is revealed.

In view of the persistent association of citizenship with nationality in the European public culture and in individual state narratives, this article challenges the wisdom of treating citizenship and equal political rights as indispensably linked, both as a matter of democratic theory and constitutional interpretation. The link between citizenship and equal political rights is ill-suited to secure the democratic self-government of persons in contemporary European states, given the increasing number of long-term resident non-citizens within their borders, facilitated by international migration and freedom of movement within the European Union. By long-term residents, I refer to persons who have acquired permanent resident status in a member state according to Article 16 of Directive 2004/38/EC or long-term resident status according to Article 4 of Directive 2004/109/EC. ' Long-term residents, I argue, share with citizens features that are decisive for their democratic inclusion. Decoupling equal political rights from citizenship will allow long-term residents to participate in democratic governance without undermining national identity and may facilitate the adoption of other post-national but normatively attractive forms of democratic governance, including, crucially, further European integration.

The article follows a positive and a negative strategy to justify its main thesis. The negative strategy seeks to dispel arguments in favour of insisting on some notion of nationality as a condition for equal political rights. These arguments derive from four values, namely collective self-determination, equal stakes, the concept of political activity, and stability. The positive strategy, a modified version of the equal stakes argument, sets out the principles which support granting equal political rights to all persons who hold a legal right to reside permanently within the territory of a state. I then discuss why the legal status of citizenship should itself be separated from equal political rights. Finally, I argue that liberal democratic European states possess the constitutional resources to adopt constitutional interpretations that align themselves with my argument.

\section{LIBERAL NATIONALISM AND THE NORMATIVE EQUIVALENCE OF NATION AND STATE}

Liberal nationalism is a family of political theories that combine liberal democratic values and policies in the domestic sphere, such as representative democracy and protection of fundamental rights, with a commitment to the nation. Liberal

\footnotetext{
${ }^{9}$ I assume here that long-term residents are generally fluent in the official language of their country of residence. Such fluency would indeed be indispensable for their participation in the political life of the country.
} 
nationalist theories broadly define what constitutes a nation (or people) in two ways. The first is a cultural understanding. On this account, the members of the nation are distinguished from non-members through cultural markers, such as language, historical narratives, and cultural practices. ${ }^{10}$ The cultural understanding does not rely on ethnicity, as any such understanding would fail the liberal limb of liberal nationalism. The second is an understanding based on political autonomy. According to it, persons constitute a nation when they share a will to engage in joint political action through institutions with which they identify. ${ }^{11}$

There are liberal nationalist theories which accord nations restricted autonomy claims rather than full political sovereignty. Yael Tamir argues for a right to national self-determination. In her work, this right enables nations to preserve themselves as distinct cultural entities, for example by promoting the use of the national language and the transmission of historical narratives and cultural practices consistent with liberal principles. ${ }^{12}$ It does not imply a right to a state. Accordingly, it does not necessarily limit citizenship to the members of one nation and is to this extent unproblematic from the post-national (but not nationeliminativist) political perspective that I am here defending.

The majority of liberal nationalists, however, claim that the bounds of the demos must be aligned, at least roughly, with the bounds of a nation. For liberal-democratic institutions to develop and take root in a society, their jurisdiction must ideally be coextensive with a nation. Citing John Stuart Mill, liberal nationalists argue that liberal-democratic institutions cannot flourish in a state with different nationalities. ${ }^{13}$ John Rawls, whose commitment to liberal nationalism is implicit in his Law of Peoples, views peoples (one could just as easily speak of nations, understood on the basis of political autonomy) as entities with normative claims that are both distinct from those of their members and restricted in scope compared to normative claims among citizens. ${ }^{14}$ This conception of peoples is based not, as Mill would have it, on what is presently possible in the regulation of international relations, but on what should generally be the case. Arguing for conceiving of the European Union as a union of nations rather than a progressive

\footnotetext{
${ }^{10}$ See P.T. Lenard, 'Inclusive Identities: The Foundation of Trust in Multicultural Communities', in G. Gustavsson and D. Miller (eds.), Liberal Nationalism and its Critics: Normative and Empirical Questions (Oxford University Press 2019) p. 160.

${ }^{11}$ See A. Stilz, 'Legitimacy and Self-Determination', in J. Knight and M. Schwartzberg (eds.), Political Legitimacy: NOMOS LXI (New York University Press 2019) p. 35-36.

${ }^{12}$ Y. Tamir, Liberal Nationalism (Princeton University Press 1993) p. 57-58.

${ }^{13}$ J.S. Mill, Considerations on Representative Government (The Floating Press 2009 [1861]) ch 16.

${ }^{14}$ J. Rawls, The Law of Peoples (Harvard University Press 1999) p. 34-35.
} 
union of individuals through their nations, ${ }^{15}$ or for limiting equal political rights to persons born into or willingly submitting to the membership conditions of the nation, ${ }^{16}$ or for a substate nation's right to secede from a state to better express the autonomy of its members, ${ }^{17}$ Anna Stilz, Pavlos Eleftheriadis, Richard Bellamy, and Rainer Bauböck all regard, more or less consistently, ${ }^{18}$ the equivalence of nation and state as a necessary condition for democracy.

Despite this consensus, the grounds for this position are contested. There are at least four justifications for the equivalence of nation and state:

(1) Collective self-determination. The equivalence of nation and state enables the shared will of nationals to be reflected in the political institutions by which they are governed..$^{19}$ This shared will expresses the autonomy of the nation, which has intrinsic value and warrants respect independent of respect for personal autonomy. It mitigates the alienating effect of state coercion, as state coercion partly reflects the values and judgements of its addressees. ${ }^{20}$

(2) Equal stakes. This justification views political action as a form of social cooperation among free and equal citizens. Given this understanding, it relies on the empirical assumption that the 'fellow-feeling' ${ }^{21}$ necessary to sustain a cooperative attitude requires that citizens have roughly equal stakes in the collective good of the political society. ${ }^{22}$ Nationality since the nineteenth century is the glue which provides societies with a sense of common fate that helps facilitate deference to collective decisions and prevent a purely self-regarding attitude. ${ }^{23}$

(3) Concept of the political. This justification views nationality as the primary group affiliation which motivates political activity in the modern world. ${ }^{24}$ Political activity is here understood to satisfy a human drive for self-assertion by providing a field of antagonism aimed at asserting the superiority of the group with

${ }^{15}$ See P. Eleftheriadis, A Union of Peoples (Oxford University Press 2020) ch 2; R. Bellamy, A Republican Europe of States: Cosmopolitanism, Intergovernmentalism and Democracy in the EU (Cambridge University Press 2019).

${ }^{16}$ See R. Bauböck, 'Democratic Inclusion: A Pluralist Theory of Citizenship', Democratic Inclusion: Rainer Bauböck in Dialogue (Manchester University Press 2018).

${ }^{17}$ See A. Stilz, Territorial Sovereignty: A Philosophical Exploration (Oxford University Press 2019) p. 133-139.

${ }^{18}$ In his writings, Rainer Bauböck at times both affirms and rejects the right of substate nationalities to political independence. Compare Bauböck, supra n. 16, p. 29-30 with R. Bauböck, 'A Multilevel Theory of Democratic Secession', 18 Ethnopolitics (2019) p. 227 at p. 232.

${ }^{19}$ Stilz, supra n. 17 , p. 104-111.

${ }^{20}$ Ibid., p. 107. See also A. Greene, 'Is Political Legitimacy Worth Promoting?', in J. Knight and M. Schwartzberg (eds.), Political Legitimacy: NOMOS LXI (New York University Press 2019) p. 78-83.

${ }^{21}$ Mill, supra n. 13, p. 286.

${ }^{22}$ Bellamy, supra n. 15 , p. 43.

${ }^{23}$ Ibid., p. 44. See C. Schmitt, The Crisis of Parliamentary Democracy (MIT Press 1985) p. 9-14.

${ }^{24}$ Bauböck, supra n. 16 , p. 8-9. 
which one identifies most intensely over other groups. ${ }^{25}$ This drive is conceived of as part of human nature; it defines the scope and limits of stable human interaction. This view is not implausible; in social psychology, social identity theory and self-categorisation theory demonstrate how persons construct their identity through identification or dissociation with a group and how they tend towards ingroup favouritism. ${ }^{26}$ Following this observation, humans tend to understand government by an authority that is not like them as a form of domination, irrespective of whether they may formally participate in electing the authority. ${ }^{27}$

(4) Stability. The equivalence of nation and state offers a good chance that political institutions will remain stable and decent in the long term. This justification is practical rather than normative; it does not preclude that other ways of organising political communities are possible and perhaps normatively more appealing. It merely asserts that, as an empirical matter, nation-states are more stable, more democratic, and provide more effective protection of equal rights and liberties than multi-national states. Consequently, if a choice between these forms of state is available, one should generally favour the nation-state.

All these justifications raise powerful objections against supporting postnational forms of political organisation. If they are sound, the stance of the federal constitutional court of Germany, the constitutional court of Austria, and the Greek council of state on equal political rights and nation-based citizenship is justified. The self-regarding and self-assertive passions of human nature cannot be constrained unless the members of a political organisation share the sense of substantive equality created by national belonging. ${ }^{28}$ Equal voice without substantive equality would give rise to highly unstable political institutions and ultimately lead to anarchy. I think that there is some truth in these objections. Nevertheless, I am sceptical as to whether they lead to the conclusion that only members of the nation, as defined in a state's citizenship law, should have equal political rights. Let me examine each justification in turn.

\section{Collective self-determination}

The argument from collective self-determination holds that the shared will of a people merits respect from both insiders and outsiders. According to Stilz's

${ }^{25}$ C. Schmitt, The Concept of the Political, expanded edn. (University of Chicago Press 2007) p. 25-27. See also P. Kondylis, Macht Und Entscheidung: Die Herausbildung Der Weltbilder Und Die Wertfrage [Power and Decision: The Creation of World Views and the Question of Value] (Klett-Cotta 1984).

${ }^{26}$ N. Ellemers and S.A. Haslam, 'Social Identity Theory', in P.A.M. Van Lange et al. (eds.), Handbook of Theories of Social Psychology (SAGE 2012). See also Lenard, supra n. 10, p. 156-157.

${ }^{27}$ R. Dworkin, Freedom's Law: The Moral Reading of the American Constitution (Oxford University Press 2005) p. 21-22.

${ }^{28}$ C. Mouffe, Politics and Passions (Centre for the Study of Democracy 2002) p. 8. 
influential account of collective self-determination, this shared will need not refer to first-order policy decisions: it can refer to adherence to a common political endeavour that is pursued through shared procedural commitments. ${ }^{29}$ By including a shared will to associate with some persons and not with others, it also determines who counts as a member of the people and who has the right to exercise political power through the political institutions. Membership of the people and the right to equal participation in the exercise of state authority and coercion are regarded as synonymous. Accordingly, the argument from collective selfdetermination deprives long-term resident non-citizens in a nation-state from any normative claim to equal political rights if they do not fulfil the criteria of membership set out by the nation in its citizenship law.

There are two issues with this argument. The first is that the collapse of citizenship into nationality undermines the liberal democratic conception of the state as an institution that ensures background conditions of justice for all persons within its jurisdiction. The reason for this is that effective deliberation on appropriate background conditions of justice presupposes the inclusion of all persons, whose life revolves around a particular jurisdiction, in collective decision-making. Unless the presence of non-nationals in a state's jurisdiction is only transitory, a citizenship law based on notions of national belonging tends to stifle this inclusion. Even inclusive conceptions of nationality based on a shared will retain a cultural majoritarian residue that lies dormant until political mobilisation activates it. Nation-based citizenship thus ultimately contributes to the rise of a class of metics, that is, of second-class citizens who may be entitled to justification of the state's laws, but who are not accorded any part in determining their content. This social condition drastically undermines the liberal democratic commitment to a conception of citizens as free and equal participants in a fair scheme of social cooperation. ${ }^{30}$

The metic analogy may seem overstated, given that liberal democracies today generally include a ius soli element in determining who qualifies for citizenship, so that the children of immigrants acquire citizenship automatically. ${ }^{31}$ This provision relies on the argument from equal stakes. By being born within the state's jurisdiction, the children of immigrants have roughly equal stakes in the collective good of the nation and may therefore be included in it. Accessible provisions for citizenship acquisition do not, however, necessarily follow from collective self-determination; according to this principle, the metic system should be retained if this is the will of the people. Otherwise, there is a risk that members

\footnotetext{
${ }^{29}$ Stilz, supra n. 17 , p. 108.

${ }^{30}$ J. Rawls, Political Liberalism, paperback edn. (Columbia University Press 1996) p. 18.

${ }^{31}$ R. Bauböck, 'Morphing the Demos into the Right Shape. Normative Principles for Enfranchising Resident Aliens and Expatriate Citizens’, 22 Democratization (2015) p. 820 at p. 829.
} 
of the nation will end up feeling alienated from their political institutions. Theorists such as Michael Walzer, Rainer Bauböck, and Anna Stilz resolve this tension by presenting the provision of options for citizenship acquisition to long-term resident non-citizens and their children as a justified constraint on collective self-determination. ${ }^{32}$

There is another aspect to the metic analogy that is interesting: both the ancient and the modern case demonstrate a preoccupation with justifying a primarily birth-based status of privilege. In the ancient case, the metic's integration in Athenian life on all but political matters was a cause for concern regarding the justification of benefits deriving from Athenian descent; ${ }^{33}$ in the modern case, citizenship tests in European nation-states are the field in which a nation tries to define itself, ${ }^{34}$ at times by presenting an idealised image of the average national. ${ }^{35}$ When they do not place unrealistic demands on applicants, however, for example by requiring specialised knowledge of a country's history, culture, and tradition, liberal democracies find that, with the important exceptions of fluency in the national language and possible socioeconomic exclusion, there is often little to distinguish their citizens from their metics. ${ }^{36}$

The second issue with collective self-determination is a broader one: it relates to its assumption that bounded political communities are necessary for democratic legitimacy. If bounded political communities have been constituted on the basis of a nationality that precedes the state, and continue to be governed according to the shared will of those who see themselves as bound to the constituted territory across generations, the decisions of their members are always legitimate. ${ }^{37}$ As Abizadeh argues, however, the notion of legitimate bounded political communities is incoherent. It fails to explain, on democratic grounds, how a collective decision can be taken on who constitutes the people without including all affected persons (boundary problem) and how power can be exercised legitimately on persons who could not participate in determining the conditions which justify coercion (externality problem). ${ }^{38}$ Given the degree of interconnectedness in the

${ }^{32}$ M. Walzer, Spheres of Justice: A Defense of Pluralism and Equality (Basic Books 1984) p. 52-61; Bauböck, supra n. 16, p. 52-54; Stilz, supra n. 17, p. 197.

${ }^{33}$ See D. Kasimis, The Perpetual Immigrant and the Limits of Athenian Democracy (Cambridge University Press 2018).

${ }^{34}$ D. Miller, Strangers in Our Midst: The Political Philosophy of Immigration (Harvard University Press 2016) p. 138-139.

${ }^{35}$ See Orgad, supra n. 6, ch 3.

${ }^{36}$ See D. Kochenov, 'Mevrouw de Jong Gaat Eten: EU Citizenship and the Culture of Prejudice' (2011) RSCAS 2011/06.

${ }^{37}$ Bauböck, supra n. 31, p. 824-826.

${ }^{38}$ A. Abizadeh, 'Democratic Theory and Border Coercion: No Right to Unilaterally Control Your Own Borders', 36 Political Theory (2008) p. 37 at p. 46-47. 
modern era, Abizadeh continues, perhaps only a global political community would have legitimate democratic authority to draw political boundaries and determine their implications. ${ }^{39}$

Invoking a pre-state principle of collective self-determination to justify state boundaries fails as a justification for bounded political communities. Since a pre-state world does not offer any established procedure of legitimate decisionmaking, a decision to constitute the state would respect the autonomy of persons only if it were unanimously agreed. It is unclear, however, how the unanimous agreement of some to exclude others from a political community would respect the autonomy of the excluded. Stilz seems to suggest that a plurality of bounded political authorities could be constituted legitimately if groups of cooperators unanimously agreed among themselves to associate on the basis of shared abstract ideals and procedural commitments. ${ }^{40}$ Her argument builds on Kant's views on the natural duty of persons to establish a state and on the need to establish a confederation of states in order to prevent a state of nature at the international level. ${ }^{41}$ Her argument, however, diverges from Kant's: instead of providing an a priori argument for the legitimacy of state authority with regard to a person subject to it, it tracks persons' actual preferences; not only does it justify state authority, but it also provides principles for the inclusion, exclusion, and secession of persons from a state.

At first glance, Stilz's argument takes persons' capacity for autonomous action more seriously than Kant's, as it extends the right to freedom of association to include the founding of political communities. The flip side, however, of viewing boundaries of membership and territory as a field for autonomous collective action, rather than as a historical contingency that is justified or disqualified by its capacity to provide conditions for personal autonomy to flourish, is that bounded political communities inevitably expose some persons, the undesirable and those unable to establish a functioning state, either to a state of nature or a status of political inequality within the state. ${ }^{42}$ Stilz, like most liberal nationalists, hastens to qualify her reliance on collective self-determination with considerations of basic justice to avoid these implications; and yet, the widespread assumption that there is potential for irreconcilable conflict between collective self-determination and justice may indicate that the insistence on this justification of bounded political communities, even when practical matters of language and stability are not at

\footnotetext{
${ }^{39}$ This rationale does not imply that non-political associations cannot unilaterally define their conditions of membership. See Rawls, supra n. 30, p. 229.

${ }^{40}$ Stilz, supra n. 17 , p. $95-98$.

${ }^{41}$ See I. Kant, Metaphysics of Morals, 6:311-313, 344.

${ }^{42}$ Hannah Arendt effectively conveys this dark side of Wilsonianism in her reflections on statelessness, human rights, and citizenship: H. Arendt, Origins of Totalitarianism (Houghton Mifflin Harcourt 1973) ch 9.
} 
issue, is based on untenable intuitions. In antiquity, a fixation with regarding the Earth as the centre of the universe led to the adoption of complex and implausible astronomical systems that preserved anthropocentric bias to the detriment of scientific explanation. Perhaps a nation-centric conception of collective selfdetermination is similarly convoluted. In my discussion of the stability argument and in the section after it, I present a conception of democracy in which a conflict between collective self-determination and justice does not arise.

\section{Equal stakes}

The argument from equal stakes determines political membership on the basis of persons having roughly equal stakes in the prosperity of a political community. ${ }^{43}$ For Richard Bellamy, the question of political membership arises from the reality of bounded polities. The existence of boundaries of membership and territory between political communities belongs to the 'circumstances of citizenship'. ${ }^{44}$ Of course, one need not be committed to the normativity of bounded political communities to concede the need for principles that determine political membership in political communities as they are presently constituted. Still, for supporters of the equal stakes argument, this reality is a fortunate event. A world divided among groups whose members live under more or less similar social, economic, and cultural conditions makes non-dominating democratic government possible. ${ }^{45}$ Equal stakes are a condition for successful collective action that is, in Dworkin's terms, communal rather than statistical. ${ }^{46}$ The tendency of persons to regard only their own interests and to find pleasure in dominating others is effectively combated by constituting a network of socioeconomic interdependence between them, and stabilising it through shared national narratives that resonate with persons as members of particular groups and cultivate solidarity and civic virtue. ${ }^{47}$

The argument from equal stakes is a powerful one. The benefits of a shared cultural identity and relative material equality for achieving the good-faith deliberation that lies at the heart of democratic governance cannot be ignored. Notice, however, that the argument has two elements: it does not suffice that a political community shares a particular culture; the argument also requires conditions of socioeconomic interdependence that are for the most part lacking in the world's

\footnotetext{
${ }^{43}$ See Bauböck, supra n. 16, p. 37-47.

${ }^{44} \mathrm{R}$. Bellamy, 'A Duty-Free Europe? What's Wrong with Kochenov's Account of EU Citizenship Rights', 21 European Law Journal (2015) p. 558 at p. 562.

${ }^{45}$ Bellamy, supra n. 15 , p. $77-81$.

${ }^{46}$ Dworkin, supra n. 27, p. 19-26.

${ }^{47}$ See M.C. Nussbaum, Political Emotions: Why Love Matters for Justice (Harvard University Press
} 2013). 
major national democracies. As of 2018, the average disposable income of the richest $10 \%$ of the population was around nine and a half times that of the poorest $10 \%$ across the OECD, up from seven times 25 years ago. ${ }^{48}$ These figures indicate that, contrary to the predictions of liberal nationalists, the existence of a national culture is typically neutral to political aims. It can be interpreted to promote redistributive policies as easily as it can be used by elites and populist leaders to channel social discontent against those who do not conform to the dominant national narrative. ${ }^{49}$ The anti-refugee and anti-LGBTQ+ rhetoric adopted by political figures in Hungary and Poland is only the most prominent contemporary European example of this instrumentalisation. Finally, it is unclear whether the equal stakes argument conceptualises the national culture as preceding the state. If this were the case, ongoing unitary nation-building projects in multi-ethnic states, such as Canada, India, or South Africa, would have to be rejected as dominating preexisting nations. This conclusion, however, would question the legitimacy and viability of most existing states. ${ }^{50}$ It would also downplay a national culture's capacity to persist and flourish without state establishment, on the one hand, and the autonomy-enhancing range of options that larger forms of political organisation secure for their individual members, on the other. If, however, the national culture is not entrenched in state-independent identifiers, but rather tied to some intimate relation of the citizen to the state's territory and history, appropriately framed to project toward a future that better serves its liberal democratic commitments, then there is no real difference between this conception of nationality and the post-national account that I am advocating.

The variety of political aims potentially served by national culture has two implications: first, a shared national culture is not an absolute requirement for political membership. Although maintaining its potential benefits may justify some restrictions to the number of non-nationals who can permanently settle within the state's territory, ${ }^{51}$ it cannot justify the view that non-citizens with a legal right to long-term residence are not full stakeholders in the political community's prosperity. Second, for a polity to be legitimate, the values reflected in the national culture must overlap, at least in part, with liberal democratic

${ }^{48}$ OECD, A Broken Social Elevator? How to Promote Social Mobility (OECD 2018) 〈https://www. oecd-ilibrary.org/social-issues-migration-health/broken-elevator-how-to-promote-social-mobility_ 9789264301085-en〉, visited 28 December 2021.

${ }^{49}$ Evidence regarding national identity's contribution to the adoption of redistributive policies is at best inconclusive: G. Gustavsson and D. Miller (eds.), Liberal Nationalism and Its Critics: Normative and Empirical Questions (Oxford University Press 2019) p. 16-17.

${ }^{50}$ See L. Vinx, 'Ernst-Wolfgang Böckenförde and the Politics of Constituent Power', 10 Jurisprudence (2019) p. 15 at p. 34-35; D. Archibugi, The Global Commonwealth of Citizens: Toward Cosmopolitan Democracy (Princeton University Press 2008) p. 231-233.

${ }^{51}$ Orgad, supra n. 6, ch 6. 
principles. Consequently, elements of the national culture that are incompatible with these principles, such as ideas of national supremacy and disregard for the well-being of non-nationals, lack political value. Promoting these elements through political means undermines the political conception of persons as free and equal and is for this reason illegitimate. ${ }^{52}$

A final way to interpret the argument from equal stakes is the appropriate proxy argument. A proponent of the equivalence between nation and state might point to the need for determinacy in defining the holders of political authority. Nationality might not be perfect, but it is an appropriate proxy for determining who has an equal stake in the state's prosperity. This argument ignores that nationbased citizenship tends to grant political rights to more persons with no or little stake in the state's prosperity than recognising political rights on the basis of longterm residence would. It may recognise political rights for second-generation emigrants who, even when they have a stake in a national culture's preservation, have no stake in the state's prosperity; ${ }^{53}$ or for dual citizens and emigrants who have integrated in their host state; or, finally, for detached cosmopolitans with sufficient mobile capital to have little or no stake in, or even means to empathise with, their native community. The inadequacy of nationality as a proxy for granting political rights is partly recognised by the practice of some states to deny voting rights to emigrants after a certain period of absence. ${ }^{54}$ By contrast, the recognition of political rights on the basis of long-term residence ensures that the holders of political authority are sedentary and thus liable to bear the consequences of political decisions, while also providing a stronger presumption that the holders of political authority are socio-economically interdependent. ${ }^{55}$

\section{Concept of the political}

The argument from the nature of political activity maintains that the equivalence between nation and state secures stability within the state by relegating the natural human drive for group-based hostility to the state's external affairs. As nationality constitutes the strongest and most irreconcilable form of distinction in the

${ }^{52}$ See Rawls, supra n. 30, p. 18.

${ }^{53} \mathrm{~W}$. le Roux, 'Economic Migration, Disaggregated Citizenship and the Right to Vote in PostApartheid South Africa', in R. Danisch (ed.), Citizens of the World: Pluralism, Migration and Practices of Citizenship (Brill 2011) p. 127-129.

${ }^{54}$ See C. López-Guerra, 'Disenfranchisement on the Basis of Nonresidency and Noncitizenship', Democracy and Disenfranchisement: The Morality of Electoral Exclusions (Oxford University Press 2014); R. Rubio-Marin, 'Transnational Politics and the Democratic Nation-State: Normative Challenges of Expatriate Voting and Nationality Retention of Emigrants', 81 New York University Law Review (2006) p. 117.

${ }^{55}$ Walzer, supra n. 32, p. 52-63. 
modern world, internal hostility can be minimised and domesticated only if a state is comprised of the same nationality. The argument's defining assumption is that the human drive for self-assertion and competition can never be fully suppressed; its expression through group-based hostility is the purest instance of political activity. I am not aware of any liberal nationalist committed to this argument. Nevertheless, it is part of a long philosophical tradition and remains relevant in contemporary political discourse and realist accounts of international affairs.

The argument's assumptions regarding human nature are hardly implausible. Kant's account of 'radical evil' is a classic formulation of the notion that envy, competition, and a desire to dominate arise naturally among humans as soon as they find themselves in the presence of others. ${ }^{56}$ Martha Nussbaum traces this tendency to anxieties developed from the experience of narcissism combined with extreme helplessness that is part of human infancy. ${ }^{57}$ A desire to dissociate oneself from that experience resonates throughout human life and motivates a drive to exert control over others. The relative physical equality among persons may necessitate some form of regular social life, but it does not preclude the possibility of violence and domination between groups. These are, according to Carl Schmitt, the circumstances of politics. ${ }^{58}$ For a society to deny them would be to leave its members exposed either to domination by an external force, or to internal strife through the reassertion of the political by group identities that elude state authority. ${ }^{59}$

Despite the plausibility of the argument's assumptions, equating political activity with the possibility for group-based hostility risks entrenching this very hostility in the relations between nationals and non-nationals. It encourages the view that Plato attributes to Clinias of Crete in his Laws: 'every State is, by a law of nature, engaged perpetually in an informal war with every other State'. ${ }^{60}$ The tendency to adopt a lower standard of proof and fewer procedural guarantees when restricting the rights of non-nationals who are considered a risk to national security, and to impose upon them measures of questionable conformity with constitutional and international human rights law, are only some implications of this bleak conception of the political. ${ }^{61}$ Its effects are just as prominent in citizenship law: on the one hand, many nation-states prohibit dual citizenship and demand

${ }^{56} \mathrm{I}$. Kant, Religion within the Boundaries of Mere Reason, 6.94.

${ }^{57}$ Nussbaum, supra n. 47 , p. $168-174$.

${ }^{58}$ Schmitt, supra n. 25 , p. 61-68.

${ }^{59}$ Ibid., p. 51-53.

${ }^{60}$ Plato, Laws, Volume I: Books 1-6 (Loeb Classical Library, Harvard University Press 1926) p. 7.

${ }^{61}$ See Korematsu v United States, 323 U.S. 214 (1944); ECtHR 19 February 2009, No. 3455/05, $A$ and Others $\mathrm{v}$ the United Kingdom; D. Dyzenhaus, The Constitution of Law: Legality in a Time of Emergency (Cambridge University Press 2006). 
intimate knowledge of the national culture as a condition of political membership; on the other hand, the practice of citizenship deprivation perpetuates the precarity of those who have ties with another nation even beyond the point of naturalisation. ${ }^{62}$ The argument's ultimate consequence is an essentialisation of nationality that is potentially dangerous in a globalised world with increasingly pluralist societies and undermines an attitude of universalistic concern, the 'cosmopolitanism of nations' which Giuseppe Mazzini and many contemporary liberal nationalists believe can be promoted and stabilised under current global circumstances only through the particular voice of national narratives. ${ }^{63}$

\section{Stability}

The argument from stability holds that the equivalence of nation and state is necessary for the long-term (typically transgenerational) viability and prosperity of the state. The argument from stability recasts many of the considerations relevant to the preceding arguments that we examined as instrumental considerations. A shared will, a sense of togetherness, socioeconomic interdependence, and even a sense of unity against outsiders contribute to nationals remaining committed to the nation, obeying its laws and supporting each other, and thus to sustaining the functions of the state.

This account appears plausible. There is some empirical evidence that homogeneous societies present higher degrees of compliance with the law than more pluralist ones. ${ }^{64}$ Although homogeneity might not be the key factor in these cases, they demonstrate that the link between stability and a homogeneous citizenry is not misguided.

Still, such merely instrumental considerations have to be set aside if a principled approach favours political equality for all long-term residents. The loss in stability and solidarity necessary to justify the denial of political equality must be very high. It must entail a real risk of collapse of a state's ability to secure rights, for example through the real possibility of lawlessness. This cannot be a risk that might arrive in the next generation, or the generation after it, as some voices expressing 'demographic anxiety' would have it. ${ }^{65}$ Contrary to autonomy-enhancing aims, such as the preservation of the natural environment, or the promotion of a liberal public culture, we cannot, consistently with a liberal system of values,

\footnotetext{
${ }^{62}$ M. Masters and S.S.F. Regilme, 'Human Rights and British Citizenship: The Case of Shamima Begum as Citizen to Homo Sacer', 12 Journal of Human Rights Practice (2020) p. 341.

${ }^{63}$ G. Mazzini, A Cosmopolitanism of Nations: Giuseppe Mazzini's Writings on Democracy, Nation Building, and International Relations (S. Recchia and N. Urbinati (eds.), Princeton University Press 2009) ch 3; Nussbaum, supra n. 47, ch 8.

${ }^{64} \mathrm{~F}$. Schauer, The Force of Law (Harvard University Press 2015) p. 73-74.

${ }^{65}$ Orgad, supra n. 6, ch 2.
} 
restrict the range of options regarded as meaningful by persons today in order to ensure the ethnic composition, or even the language and national culture of future generations. This is because, unlike the natural environment or a system of equal rights and liberties, particular ethnicities, languages, and national cultures do not have intrinsic value were we to imagine persons in a position to choose one or the other prior to being born and raised in them. ${ }^{66}$ In any case, the argument from stability seems to apply better at the level of granting long-term residence to persons rather than recognising equal political rights. ${ }^{67}$ As Orgad argues, admission policy considerations may legitimately include concerns about preserving a particular majority group within a state's jurisdiction; ${ }^{68}$ but from the moment that persons who have not adopted the national identity of the people are permitted to live permanently among them, the possible benefits of nationality have already been affected. The preservation of a homogeneous nation can no longer be invoked to justify withholding political rights.

The argument from stability also seems to downplay the benefits for stability and solidarity that derive from the unconditional democratic inclusion of persons who have already been permitted to settle within the state's territory. It is precisely this inclusion that enables members of a minority group to embrace a reasonable constitutional democracy not as a modus vivendi, but as a fair scheme of social cooperation which ensures 'the liberty of the group's members consistent with the equal liberties of other reasonable free and equal persons' ${ }^{69}$ In a similar vein, Kokott notes that the coexistence of different cultural communities can reinforce a person's commitment to a state's prosperity rather than undermine it. ${ }^{70}$ Instead of undermining stability domestically, a post-national conception of political community can enhance stability domestically as well as internationally, as increased communication between nations and deliberation among persons

\footnotetext{
${ }^{66}$ Here I adopt without argument a Kantian (and Rawlsian) conception of the self. Readers with communitarian attachments will without doubt find this account unsatisfactory.

${ }^{67}$ López-Guerra, supra n. 54, p. 88-89. This article cannot delve into the practical issues pertaining to the enforcement of migration policy. Despite the potential destabilising effect that uncontrolled immigration may have for a state, it is doubtful that the denial of political rights to long-term residents undercuts this effect. Denying political rights to compensate for the ineffective enforcement of migration policy is an unprincipled approach.

${ }^{68}$ Orgad, supra n. 6, ch 6.

${ }^{69}$ Rawls, supra n. 14, p. 148-152. See also Rawls, supra n. 30, p. 161.

${ }^{70} \mathrm{~J}$. Kokott, 'Die Staatsrechtslehre und die Veränderung ihres Gegenstandes: Konsequenzen von Europäisierung und Internationalisierung' [Public Law and its Change of Object: Consequences of Europeanisation and Internationalisation], Die Staatsrechtslehre und die Veränderung ihres Gegenstandes. Gewährleistung von Freiheit und Sicherheit im Lichte unterschiedlicher Staats- und Verfassungsverständnisse. Risikosteuerung durch Verwaltungsrecht. Transparente Verwaltung Konturen...: Berichte und Diskussionen auf der Tagung der Vereinigung der Deutschen Staatsrechtslehrer in Hamburg vom 1. bis 4. Oktober 2003 (De Gruyter 2004) p. 27-28.
} 
coming from a plurality of backgrounds will promote mutual understanding, and therefore trust, provided that the structure of the political process and social life is such that makes good-faith deliberation possible.

Finally, the concern for stability is connected to an implausible conception of democracy whereby democracy refers merely to the will of the majority. Advocates of the normative equivalence between nation and state rightly emphasise that the various factions within a pluralist society are more likely to dominate one another, if that opportunity arises, than to compromise and deliberate toward a commonly acceptable decision. ${ }^{71}$ Better then to externalise the risk of domination in the international sphere, they argue, than to have permanent minorities within a state whose views and interests are consistently disregarded by the majority. The problem here is that the risk of polarisation is an inherent feature of societies with conscientious citizens: the more persons are permitted to exercise their own reason to develop their conceptions of justice and the good, the more likely they are to arrive at different conclusions on what collective decisions should be made. ${ }^{72}$ Even without the propensity for tribalism, persons reflecting independently and unrestricted by the limits of an oppressive culture will make different judgements on any practical issue of some complexity. ${ }^{73}$ Approaching matters from their own limited perspective, they will naturally disregard some of the needs and interests of others. Without adding further elements beyond majority rule to our definition of democracy, democracy appears too thin to provide any legitimacy to collective decisions.

Deliberation must be a necessary feature of any plausible conception of a stable democracy. Unless persons submit their political opinions to debate and counterargument, majority decisions are bound to be unjust, perhaps even radically so, to some members of the political community. This is not merely because there may be reasonable disagreement on what justice requires in some cases; this is a reason to ground our conception of democracy on majority rule rather than unanimity. The point is that, unless persons deliberate prior to casting their votes, they are likely to vote against proposals that may be supported by arguments that they would themselves regard as the better ones, had they engaged with them. David Estlund makes the same point by distinguishing between what he calls fair and epistemic proceduralism. On the one hand, fair proceduralism is the view that decision-making based on equal participation and majority rule is all there is to democracy. On the other hand, epistemic proceduralism holds that, in order to have moral authority, a democratic process must be more likely to arrive at just

\footnotetext{
${ }^{71}$ Bellamy, supra n. 15 , p. 66.

${ }^{72} \mathrm{~J}$. Waldron, Law and Disagreement (Oxford University Press 1999).

${ }^{73}$ For this fact of reasonable pluralism, see Rawls, supra n. 30, p. xvi-xvii.
} 
decisions than any other equally fair procedure. ${ }^{74}$ The public recognition of the procedure derives from its deliberative character. ${ }^{75}$ There is then a strong case to argue that unreflective collective decision-making is not only more likely to be unjust, but is also illegitimate.

The literature on the benefits of institutionalised forms of deliberative democracy is vast and much of it need not concern us here. ${ }^{76}$ The point that is relevant to this article is that formal deliberative processes, such as formal debates among a randomly selected representative mini-public, demonstrate surprising quality even among highly heterogeneous participants divided on ethnic, cultural, and religious grounds. ${ }^{77}$ Examples from areas with diverse socioeconomic and cultural conditions, such as France, ${ }^{78}$ Ireland, ${ }^{79}$ and Colombia ${ }^{80}$ indicate that the possibility of resolving conflicts justly through effective deliberation is a viable option for pluralist societies. John Dryzek goes as far as arguing that the process of democratisation is a process of building deliberative capacity. ${ }^{81} \mathrm{It}$ is not a stretch to add that stabilising a liberal democracy is a process of maintaining deliberative capacity.

\section{THE POSITIVE ARGUMENT FOR POLITICAL RIGHTS ON THE BASIS OF LONG-TERM RESIDENCE}

This section elaborates on the principle behind granting equal political rights to long-term residents. If nationality is rejected as a principle to determine who should be entitled to membership in a political community, what is the alternative?

Democratic inclusion theory examines what principles are relevant for granting membership to political communities. We may distinguish between speculative

${ }^{74}$ D. Estlund, Democratic Authority: A Philosophical Framework (Princeton University Press 2007) p. 8.

${ }^{75}$ Ibid., p. 9.

${ }^{76}$ For an overview, see A. Bächtiger et al. (eds.), The Oxford Handbook of Deliberative Democracy (Oxford University Press 2018).

${ }^{77}$ H. Landemore, Open Democracy (Princeton University Press 2020) p. 187-191.

${ }^{78}$ É. Buge and C. Morio, 'Le Grand débat national, apports et limites pour la participation citoyenne' [The Great National Debate, its contribution and limitations to citizen participation], Revue du droit public (2019) p. 1205.

${ }^{79}$ D.M. Farrell and J. Suiter, Reimagining Democracy: Lessons in Deliberative Democracy from the Irish Front Line (Cornell University Press 2019).

${ }^{80}$ J. Steiner et al., Deliberation Across Deeply Divided Societies: Transformative Moments (Cambridge University Press 2017).

${ }^{81}$ J.S. Dryzek, 'Democratization as Deliberative Capacity Building', 42 Comparative Political Studies (2009) p. 1379. 
and practical democratic inclusion theory. On the one hand, speculative democratic inclusion theory examines how political communities should be constituted. It asks questions such as: should political communities be plural, reflecting local needs and cultural preferences, or singular, comprising all humanity? Should plural political communities be conceived only horizontally, for example as a system of territorial states with absolute sovereignty within their jurisdiction, or also vertically, allowing for the distribution of competences between smaller political communities and larger ones that encompass them? How should plural political communities decide about their competences, as well as their boundaries of membership and territory? On the other hand, practical democratic inclusion theory assumes the reality of plural political communities in the form of territorial states. It asks how membership of territorial states should be distributed. This section is concerned with practical democratic inclusion theory.

In the previous section, I rejected nationality as a principle of democratic inclusion. I also rejected an interpretation of the principle of equal stakes that supported nationality. There is, however, a post-national reading of the equal stakes principle. Thomas Christiano speaks of a 'common world', a set of circumstances among a group of persons in which the fundamental interests of each person are implicated in how that world is structured in a multitude of ways. ${ }^{82} \mathrm{He}$ explicitly rejects that being part of this common world entails cultural, ethnic, or national homogeneity. ${ }^{83}$ This reading of the equal stakes principle is much more accommodating to non-nationals than its iteration in the previous section. It provides the basis for my argument for equal political rights for long-term residents.

Long-term residents share with citizens features that are decisive for the equal stakes principle. Like citizens, they are sedentary within the state. Their state of residence constitutes the basis of their activities, the context in which their life plans develop. Their fundamental political interests are interests conducive to leading an autonomous life: interests in equal rights, liberties, and opportunities, as well as in decent conditions of socioeconomic justice. ${ }^{84}$ These are all intimately tied to the stability and prosperity of their state of residence; they differentiate long-term residents from mere transients, such as tourists and guest workers; and they cannot be pursued effectively without equal political rights that enable long-term residents to vote for concrete policies and have a say in setting the political agenda.

${ }^{82}$ T. Christiano, The Constitution of Equality: Democratic Authority and Its Limits (Oxford University Press 2008) p. 81.

${ }^{83}$ Ibid., p. 82.

${ }^{84}$ See K. Angell, 'A Life Plan Principle of Voting Rights', 23 Ethical Theory and Moral Practice (2020) p. 125 at p. $131-133$. 
The equal stakes principle provides a post-national principle of democratic inclusion that is free from the problems associated with accounts of democratic inclusion based only on affected interests or subjection to state coercion. ${ }^{85}$ It provides a threshold of interests relevant to democratic inclusion that is consistent with states being the primary and most effective structure for furthering social justice in the modern world; and it takes due account of state coercion's autonomy-violating potential without rendering democratic government unmanageable through the inclusion of transients. Of course, this is not to downplay the value of principles based on affected interests and coercion or domination for speculative democratic inclusion theory. ${ }^{86}$

\section{AdDRESSING THE EMPIRICAL EQUIVALENCE BETWEEN NATION AND CITIZENSHIP}

The reader of the previous sections, perhaps motivated by cosmopolitan sympathies, may be persuaded by my responses to the main justifications for the principle of 'one state, one nation'. She may still wonder, however, why a post-national conception of political community should be pursued by granting equal political rights to long-term residents and not by changing the state's citizenship laws. This

${ }^{85}$ See R.E. Goodin, 'Enfranchising All Affected Interests, and Its Alternatives', 35 Philosophy \& Public Affairs (2007) p. 40; D. Owen, 'Constituting the Polity, Constituting the Demos: On the Place of the All Affected Interests Principle in Democratic Theory and in Resolving the Democratic Boundary Problem', 5 Ethics \& Global Politics (2012) p. 129 at p. 146; Abizadeh, supra n. 38, p. 39-42.

${ }^{86}$ The flip side of the post-national conception of the equal stakes principle is that, other things being equal, nationals who permanently reside outside their country of origin should not be entitled to equal political rights in this country. The Federal Elections Act (Germany) is an example of this approach. Section 12 provides that, in order to be eligible to vote in federal elections, a German citizen who does not reside in Germany must have had a domicile or have otherwise been permanently resident in the Federal Republic of Germany for an uninterrupted period of at least three months in the last 25 years or must have, for other reasons, become familiar, personally and directly, with the political situation in the Federal Republic of Germany and be affected by it. Of course, if the post-national conception of the equal stakes principle is persuasive, the asymmetry between the duration of residence necessary to acquire long-term resident status and the duration of residence outside one's country required to lose the right to vote lacks justification, particularly since the criterion of being personally and directly familiar with and affected by the political situation of the Federal Republic of Germany is likely to address instances of injustice that cannot be predicted in advance. There is a strong case, however, for differentiating between permanently residing in the territory of an EU member state other than the member state of one's nationality and permanently residing outside the EU, given the degree of political and economic interdependence of EU member states. I am grateful to an anonymous reviewer for suggesting that I clarify my position on this point. 
is, after all, the approach favoured by the federal constitutional court of Germany and the constitutional court of Austria.

Before proceeding with the argument, let me highlight the current background on non-citizen political rights. In many states, long-term residents hold some political rights that are not as extensive as the political rights of citizens. The trend of recognising voting rights for non-citizens in local, municipal and, regarding federal states, state elections, is well documented. In 2020, the Scottish parliament extended the right to vote in Scottish elections to all persons legally residing in Scotland, irrespective of citizenship. ${ }^{87}$ Several Commonwealth of Nations member states, including the United Kingdom, further recognise full voting rights for Commonwealth citizens under certain conditions. The trend is consistent with the equal stakes argument I provided in the previous section. It is also mirrored in the practice of some states to withhold voting rights from citizens who are not resident in their country of origin and who are not familiar with and affected by its political situation. ${ }^{88}$ Admittedly, this practice is counterbalanced by increasingly facilitating non-resident citizen participation in national elections. ${ }^{89}$ This tension only demonstrates, however, the inconsistency that ensues from regarding liberalism and collective self-determination as incommensurable value systems, the former concerned with preserving personal autonomy in a cooperative setting by including all persons whose fundamental interests are affected by state coercion in collective decision-making, the latter focusing on securing the ability of nationals to govern themselves. ${ }^{90}$

These non-citizen voting rights initiatives are regarded as a threat to the equal political status secured by citizenship. This is the concern motivating the German and Austrian case law that I referred to earlier. ${ }^{91}$ This valid concern, however, is often overshadowed by a commitment to the equivalence between nation and state, that is, by the view that only nationals should have equal political rights. To demonstrate this, consider a case from Austria and one from Greece. In the Austrian case, the Austrian constitutional court rejected the legislature's power

\footnotetext{
${ }^{87}$ Section 1(9) of the Scottish Elections (Franchise and Representation) Act 2020.

${ }^{88}$ See s. 1 of Representation of the People Act 1985 (UK); s. 12 of the Federal Elections Act (Germany); s. 1 in conjunction with s. 16(2) of Folketing (Parliamentary) Elections Act (Denmark).

${ }^{89}$ R. Bauböck, 'Stakeholder Citizenship and Transnational Political Participation: A Normative Evaluation of External Voting', 75 Fordham Law Review (2007) p. 2393 at p. 2393.

${ }^{90}$ Schmitt, supra n. 23, chs $1,2$.

${ }^{91}$ See the German Federal Constitutional Court's and the Austrian Constitutional Court's judgments on foreigner voting rights: BVerfGE 83, 37; BVerfGE 83, 60; VfGH 30.06.2004, G 218/03 47-48; R.C. van Ooyen, Die Staatstheorie des Bundesverfassungsgerichts und Europa: Von Solange über Maastricht und Lissabon zur EU-Grundrechtecharta [The Theory of State of the Federal Constitutional Court and Europe: From Solange through Maastricht and Lisbon to the Charter of Fundamental Rights of the European Union], 8th edn. (Nomos 2020) p. 29-32, 41-45.
} 
to restrict the voting rights of non-resident citizens. ${ }^{92}$ Citizens retained a right to vote in Austrian national elections even if none of their fundamental interests was tied to the prosperity of the Austrian state. In the Greek case, the Greek council of state declared a law that enabled immigrant children to apply for Greek citizenship and granted local voting rights to resident third-country nationals to be unconstitutional. ${ }^{93}$ Fundamental interests were considered insufficient to ground equal political rights in the absence of proof of national belonging. The nationals of Luxembourg have expressed the same view: a constitutional referendum that proposed the recognition of the right to vote in national elections for long-term residents was rejected in 2015. These comparative considerations demonstrate that the equivalence between nation and citizenship is firmly entrenched in the constitutional case law of various European nation-states, as well as in the minds of many of their nationals. Consequently, amendments to the state's citizenship law are viewed as illegitimate encroachments on the self-understanding of a nation.

In this environment, efforts to liberalise access to citizenship, as much of the academic discourse maintains, ${ }^{94}$ risk being interpreted by the public as efforts to redefine national identity. The members of the dominant cultural community are likely to alienate themselves from a public authority that appears to interpret their national identity in a different way than they do. A perceived attempt to rob the nation of its identity would be bound to meet strong resistance from the native national population. Importantly, non-nationals may also be disinclined to naturalise even if the receiving state has a flexible notion of nationality, either because they continue to identify as a member of the nation to which they were born, or because one of the states involved does not tolerate dual citizenship.

Dissociating political rights from citizenship would better respond to both claims for democratic inclusion and the preservation of the self-understanding of the nation. ${ }^{95}$ It would establish that these are two separate matters. On the one hand, long-term residents would be included in the collective decisionmaking process, by which state authority is democratically legitimised. On the other hand, the majority nation would retain control over its conditions of membership, and thus preserve its sense of togetherness and its members' ability to enjoy meaningful relations with each other. The separation of citizenship and political right-holding would be consistent with Walzer's distinction between

${ }^{92} \mathrm{VfGH}$ 16.03.1989, G218/88.

${ }^{93}$ Greek Council of State 460/2013.

${ }^{94}$ Bauböck, supra n. 16, p. 37-47; J. Carens, The Ethics of Immigration (Oxford University Press 2013) p. 162-163; M. van den Brink, 'Revising Citizenship within the European Union: Is a Genuine Link Requirement the Way Forward?' (EUI Working Papers 2020) p. 6-9.

${ }^{95}$ See López-Guerra, supra n. 54, p. 84-90. 
the national club or family and the state. ${ }^{96}$ Although it would deprive nationality of its political status, it would preserve its social status and the integrity of national identity. Consequently, it would be preferable to redefining nationality through amending a nation-state's citizenship laws.

De Schutter and Ypi argue that citizenship acquisition should be mandatory for long-term residents, so that they may share in the burdens of citizenship. ${ }^{97}$ They refer to the duty to pay taxes, jury duty, and mandatory military service as such legal burdens. ${ }^{98}$ Despite the theoretical appeal of their argument, their concern can for the most part be addressed outside the framework of citizenship. The recognition of political rights for long-term residents can for the most part correlate with the imposition of political duties. Admittedly, the duty to perform military service is a difficult case. One may wish to question whether it is a justifiable practice in a stable liberal democracy in the first place. ${ }^{99}$ This is a task that I cannot treat adequately within the confines of this article. One cannot fail but notice, in any case, that De Schutter and Ypi's concern has little application in the context of EU member states. Long-term residents are already required to pay taxes in their state of residence; the duty to perform jury service is limited in EU member states; and mandatory military service is in decline. ${ }^{100}$ As a consequence, long-term residents are either already required to perform legal duties that are typically perceived to correlate with political rights, or the asymmetry between the political duties of citizens and long-term residents is likely to be minimal.

\section{DemocratiC INCLUSION AND THE LIBERAL DEMOCRATIC CONSTITUTION}

The relevance of deliberation and representation for constitutional interpretation in liberal democracies

In this final section, I argue that deliberative democracy and my reading of the equal stakes argument give a more attractive understanding of liberal democracy than the liberal nationalist identification of democracy with national

\footnotetext{
${ }^{96}$ Walzer, supra n. 32, p. 52. The distinction is also reflected in Art. 1(3) of the Greek Constitution.

${ }^{97}$ H. De Schutter and L. Ypi, 'Mandatory Citizenship for Immigrants', 45 British Journal of Political Science (2015), p. 235 at p. 239-242.

${ }^{98}$ De Schutter and Ypi, supra n. 97, p. 239-240.

${ }^{99}$ See, for example, A.J. Simmons, Justification and Legitimacy: Essays on Rights and Obligations (Cambridge University Press 2012) ch 3.

${ }^{100}$ As of 2021, military service is mandatory in Austria, Denmark, Greece, Norway, Portugal, Sweden, Switzerland, and Estonia. See World Population Review, 'Countries with Mandatory Military Service 2021' 〈https://worldpopulationreview.com/country-rankings/countries-withmandatory-military-service $\rangle$, visited 28 December 2021.
} 
self-determination. If my argument is correct, references to the 'people' and 'popular sovereignty' in liberal democratic constitutions are best interpreted to include long-term residents, if the constitutional text allows this interpretation. My argument assumes an inclusive legal positivist thesis: in liberal democracies, the consistency of a norm with certain moral principles, typically found in constitutions and constitutional texts, is a precondition for the status of the norm as valid law. ${ }^{101}$ The principles themselves can raise disagreements on how they are to be properly understood and applied, but this does not necessarily mean that they are indeterminate and thus unable to guide legal interpretation. The relevant principle for my argument is the principle of democratic rule. The way we interpret what a liberal democratic constitution's commitment to democracy means determines how we are to understand who is included in the people. In the preceding sections, I argued against the normative equivalence between nation and state and in favour of deliberative democracy and including everyone, whose fundamental interests are implicated by political decisions, in collective decisionmaking. To succeed in my argument in this section, I need to demonstrate that the defining features of liberal democracies both fit and are best understood according to these latter notions. I argue that they are.

First, it is necessary to refute two accounts of what liberal democracies claim to do: the first is that they claim to represent the people's common preferences; the second is that they claim to represent the will of the nation. What is lacking in both accounts is a proper assessment of the role of parliament. Parliament is redundant in either account: the preferences or the will of the nation can be served just as well by a single representative, say a president, liable to recall if the people feel that the bond of representation has been severed. ${ }^{102}$ Parliament would then be a relic of the past, whose majority would only be legitimately empowered to provide political support to the government that has been directly or indirectly chosen by the nation. This view may be consistent with a number of related global trends, such as the general disaffection with parliamentarism, ${ }^{103}$ the rise of populism, ${ }^{104}$ and the expansion of the executive's law-making powers. ${ }^{105}$ It is not, however, a view that reflects the essential features of liberal democracies. The

${ }^{101}$ M. Kramer, Where Law and Morality Meet (Oxford University Press 2004) ch 2; M. Kramer, 'Incorporationism, Inclusivism, and Indeterminacy', SSRN Electronic Journal (2021).

${ }^{102}$ Schmitt, supra n. 23, p. 34; Waldron, supra n. 72, p. 54.

${ }^{103}$ R.J. Dalton, Democratic Challenges, Democratic Choices: The Erosion of Political Support in Advanced Industrial Democracies (Oxford University Press 2004).

${ }^{104}$ C. de la Torre (ed.), Routledge Handbook of Global Populism (Routledge 2018); J.W. Müller, What Is Populism? (University of Pennsylvania Press 2016).

${ }^{105}$ A. Vermeule, Law's Abnegation: From Law's Empire to the Administrative State (Harvard University Press 2016). 
two accounts fail to explain why parliament remains a defining feature of liberal democracies, although their popularity may be telling of parliamentary democracy's failures. If what is distinctive about parliament is not merely its capacity to represent (although this is certainly a necessary aspect of it), then we must seek its merit elsewhere.

Collective decision-making in liberal democracies is generally conceived of and structured as a deliberative process at the level of parliamentary representatives. ${ }^{106}$ Legislators are expected to present reasons for their political positions, both to other legislators and to the public. Their power to make decisions is secured by a free mandate. The free mandate emphasises the deliberative, and thus inclusive, aspect of their mission. They do not simply express the interests of their constituents; ideally, they seek to arrive at a substantively correct outcome or, to adopt Rousseau's terminology, a genuine expression of the general will. At the same time, their accountability to all their constituents motivates them to take account of conflicting interests in a way that their constituents would be unlikely to do in a direct democracy. These general features and the particular rules of parliamentary procedure that pertain to every liberal democracy provide public reasons to think that the results of deliberation in parliament will tend to have a higher (albeit not necessarily much higher) epistemic value than the results of deliberation in a direct democracy, in which many of these features could not be replicated or would undermine freedom of expression. ${ }^{107}$ The institutional promotion of decisions that approximate consensus, and, therefore, of decisions that tend to be based on deliberation, is also evident in the special procedural conditions typically required for amending the constitution. ${ }^{108}$ The deliberative character of parliament and its centrality in liberal democracies advocate strongly for conceiving liberal democracies as instantiations of epistemic proceduralism.

This is not to say that contemporary parliamentary practice perfectly reflects this idealisation. ${ }^{109}$ In contemporary politics, the deliberative virtues of parliamentary democracy are undermined in a number of ways. The election and re-election of legislators is usually dependent on their endorsement by political parties and on their continued loyalty to these parties. The financing of political campaigns often exposes legislators to the need of supporting the interests of

\footnotetext{
${ }^{106}$ Waldron, supra n. 72, ch 4.

${ }^{107}$ Estlund, supra n. 74, p. 187-192, 201-204; A. Hamilton et al., The Federalist Papers (Oxford University Press 2008 [1787]) p. 53.

${ }^{108} \mathrm{R}$. Albert, 'The Structure of Constitutional Amendment Rules', 49 Wake Forest Law Review (2014) p. 913.

${ }^{109}$ See Schmitt, supra n. 23, ch 2.
} 
lobbyists. In constituency-based electoral systems, their commitment to the common good is constrained by promises made to influential constituents. The biases of their constituents force them to adopt, if they are to have a chance at election or re-election, an impoverished rhetoric that constrains their ability to decide in accordance with the common good on high-profile matters. Finally, parliamentary democracy constitutes a process of elite deliberation that often appears condescending and distrustful of the people. ${ }^{110}$ The privileges which guarantee a representative's ability to deliberate on equal terms also create a distinctive social group of professional politicians with interests and preferences which may diverge from the electorate. Crucially for the main argument of this article, the public recognition of the epistemic value of parliament's decisions is severely undermined when certain groups of addressees of its decisions are not represented at all.

This means that the legitimacy of parliament's decisions is a matter of degree. The quality of parliament's deliberation and its representative composition create a weaker or stronger presumption of legitimacy. Nevertheless, the presumption itself is, contrary to what the two accounts of democracy that I discussed earlier would require, a consequence of both aspects. The best explanation of liberal democracy's claim to moral authority remains one that makes its moral force depend on both its representative and its deliberative character.

\section{The constitution's sovereign subjects}

In the previous section I argued that the constitutionally entrenched commitment of liberal democratic states to democracy is best interpreted with reference to a dual commitment to deliberative procedures and the representation of those with an equal stake in public affairs. If this claim is plausible, then this understanding of democracy should guide the decisions of legal officials, including judges, legislators, and the government, in hard cases of legal and constitutional interpretation within their field of competence. Regarding constitutional adjudication, this approach favours an interpretation of popular sovereignty that ties the recognition of political rights to stable subjection to state authority. For an example of this approach, consider the case law of the Australian high court on prisoner voting

${ }^{110}$ J.S. Fishkin, 'Deliberative Democracy and Constitutions', 28 Social Philosophy and Policy (2011) p. 242 at p. 246; Landemore, supra n. 77, p. 40-44. See J.S. Fishkin, Democracy When the People Are Thinking: Revitalizing Our Politics Through Public Deliberation (Oxford University Press 2018). 
rights. In Roach v Electoral Commissioner, ${ }^{111}$ the court declared unconstitutional a statute implementing a blanket ban on prisoner voting rights. The high court based its judgment on Articles 7 and 24 of the Australian constitution, which required that senators and members of the house of representatives be 'directly chosen by the people', and on the structure of the Australian constitution, which protects representative government. The majority opinion identified the rationale of this principle with the notion that 'the exercise of the franchise is the means by which those living under that system of government participate in the selection of both legislative chambers, as one of the people of the relevant State and as one of the people of the Commonwealth'. ${ }^{112}$ Despite referring to Australian citizens in this case, this reasoning applies with equal force to non-citizen long-term residents.

In practice, however, constitutional courts have identified the people with a state's citizenry, and even placed substantive limits on how citizenship is to be determined. This interpretation is problematic where it is not grounded on a clear constitutional provision. Often this is not the case; the identification of the people with the citizenry is instead based on constitutional preambles rather than the constitutional text itself. ${ }^{113}$ Preambles often contain some expression of a strong collective identity that is identified as the constituent subject. ${ }^{114}$ Some refer to a particular people, rather than the people, as sovereign (constitution of Germany 1949). Others identify the nation as sovereign (constitution of Hungary 2011). These are all expressions of the equivalence between nation and state. The legal status of preambles has seen a progressive shift in recent years from symbolic to interpretatively valuable or even substantive. ${ }^{115}$ Nevertheless, their employment in legal interpretation is more a matter of judicial empowerment, ${ }^{116}$ or populist capture, ${ }^{117}$ than of liberal democratic principle. After all, many preambles to constitutions contain statements that are clearly incompatible with any liberal democratic framework, such as references to a specific religion or deity. Therefore, we can view any contradiction between a judicial interpretation that legally incorporates a preamble's identification of state authority with a nation and one that

${ }^{111}(2007) 233$ CLR 162.

${ }^{112}$ Ibid., para. 83 .

${ }^{113}$ BVerfGE 83,37 , p. 51-52.

${ }^{114} \mathrm{~L}$. Orgad, 'The Preamble in Constitutional Interpretation', 8 International Journal of Constitutional Law (2010) p. 714 at p. 716-717; H. Kelsen, General Theory of Law and State (Transaction Publishers 2006 [1949]) p. 260-261.

${ }^{115}$ Orgad, supra n. 114, p. 722-731.

${ }^{116}$ Ibid., p. 726-728.

${ }^{117} \mathrm{G}$. Halmai, 'Abuse of Constitutional Identity. The Hungarian Constitutional Court on Interpretation of Article E) (2) of the Fundamental Law', 43 Review of Central and East European Law (2018) p. 23. 
better fits the institutional framework of liberal democracies, in particular its deliberative and representative character, as a contradiction between a higher order constitutional principle of deliberative democracy and a lower order policy of mobilising a historically contingent group of persons to support an often recently established, and therefore fragile, de facto authority. The constitutional principle that better explains a liberal democracy's institutions must prevail. In this case, the appeal to historical intentions is no stronger than it is in other contexts of constitutional interpretation. ${ }^{18}$

Nevertheless, understanding popular sovereignty on the basis of equal stakes rather than citizenship does not necessarily mean that a constitutional court with the power to strike down legislation is automatically empowered to strike down citizenship laws that do not recognise long-term residents as citizens, or that it is empowered to require the recognition of political rights independent of citizenship to long-term residents, in line with what I proposed in the preceding section. Birthright citizenship, even if not necessary for independent states, usually serves as an appropriate proxy for equal stakes. In a less mobile world, having one's fundamental interests connected to a particular state and belonging to its citizenry would typically overlap. In states that are homogeneous or adopt inclusive citizenship regimes, this is still the case. A constitutional court would thus overstep its deliberative competence if it were to legislate in the place of parliament.

Still, this interpretation of popular sovereignty bears two implications: first, a constitutional court cannot interfere, as it has in Germany, Austria and Greece, with legislation that extends political rights; second, a constitutional court with the power to strike down, or require the adoption of, legislation in accordance with constitutional provisions, may, in cases of large-scale underrepresentation of a state's population of residents, to the point of undermining citizenship's capacity to function as a plausible proxy for subjection to state authority, require parliament to remedy this discrepancy by legislating a more accurate proxy. The boundaries of this power are hard to draw in practice. Nevertheless, any plausible account of a liberal democratic state that incorporates the democratic principle into law presupposes that such boundaries exist. For example, it would be impossible to label a state that limits the franchise on the basis of race or gender as a liberal democracy.

\section{ConClusion}

In his introduction for the 1963 reprint of the Concept of the Political, Carl Schmitt declares the end of the classic notion of state. With it, he laments the

${ }^{118}$ R. Dworkin, Law's Empire (Hart Publishing 1998) ch 10. 
passing of rigid political distinctions - between peace inside and war outside state borders, between criminals within and enemies without and, by implication, between nationals and non-nationals, citizens and non-citizens - distinctions which, by virtue of their rigidity, inspired security in one's status. ${ }^{119}$ Concern for such security underpins, as we saw, much of the academic literature and constitutional jurisprudence in support of the equivalence between nation and state. In this article, I tried to dispel some of these concerns and draw attention to the most striking implication of this position: the risk of perpetual political exclusion of non-nationals who are in every significant regard contributors to the state's prosperity as well as its social and cultural life more broadly. I argued that a metic-type political affiliation to a state must lead to full political membership. Transitory regimes of membership - and perhaps territory - are best understood consistent with Kant's notion of cosmopolitan right, that is, as enablers of an ever closer union between persons. ${ }^{120}$ Full political membership, however, need not imply transition from one nation to another. A natural fading of national belonging once a person emigrates to another state is neither likely nor desirable for liberal democracies operating within a globalised world. As citizenship remains closely linked to nationality in the public sphere, separating equal political rights from citizenship may be the most effective policy for including long-term residents in political decision-making without undermining the value of national belonging. Properly construed, the constitutions of liberal democracies provide no impediment to this policy: the centrality of deliberation and representation for a compelling account of democratic legitimacy only speak in its favour.

${ }^{119}$ C. Schmitt, Der Begriff des Politischen: Text von 1932 mit einem Vorwort und drei Corollarien (Duncker \& Humblot 1987) p. 4-9.

${ }^{120}$ See A. Hoogenboom, 'In Search of a Rationale for the EU Citizenship Jurisprudence', 35 Oxford Journal of Legal Studies (2015) p. 301; N.N. Shuibhne, "The "Territory of the Union" in EU Citizenship Law: Charting a Route from Parallel to Integrated Narratives', 38 Yearbook of European Law (2019) p. 267. 